\title{
Development of a TaqMan Array card to target 21 purulent meningitis-related pathogens
}

Chengna Zhao ${ }^{1,2 \dagger}$, Xi Wang ${ }^{3 \dagger}$, Chao Zhang ${ }^{2}$, Bing Liu ${ }^{3}$, Hongbo Jing ${ }^{4}$, Lihua Ming ${ }^{5}$, Hua Jiang ${ }^{2}$, Yuling Zheng ${ }^{2}$, Peng Liu ${ }^{2^{*}}$, Gang Liu ${ }^{3^{*}}$ and Yongqiang Jiang ${ }^{1,2^{*}}$

\begin{abstract}
Background: Purulent meningitis (PM) is a serious life-threatening infection of the central nervous system (CNS) by bacteria or fungi and associated with high mortality and high incidence of CNS sequelae in children. However, the conventional cerebrospinal fluid (CSF) culture method is time-consuming and has a low sensitivity.

Methods: Our study developed a real-time PCR-based purulent meningitis-TaqMan array card (PM-TAC) that targeted 21 PM-related pathogens and could produce results within $3 \mathrm{~h}$. Primers and probes were adapted from published sources possibly. The performance of them were evaluated and optimized and then they were spotted on TAC.

Results: The PM-TAC showed a sensitivity and specificity of 95 and 96\%, respectively. For all of the 21 targeted pathogens, the PM-TAC assay had a LOD ranging from 5 copies/reaction to 100 copies/reaction, an intra-assay variation of $0.07-4.45 \%$, and an inter-assay variation of $0.11-6.81 \%$. Of the 15 CSF samples collected from patients with PM after empiric antibiotic therapies, the positive rate was 53.3\% (8/15) for our PM-TAC assay but was only 13. $3 \%(2 / 15)$ for the CSF culture method. Of the 17 CSF samples showing negative CSF culture, the PM-TAC assay identified a case of Neisseria meningitidis infection. Furthermore, all of the 10 CSF samples from patients without CNS infection showed negative for the PM-TAC assay.

Conclusions: Our PM-TAC assay also demonstrated that the pathogen loads in the CSF samples correlated with the severity of PM. Thus, the PM-TAC may be helpful to improve the prognosis of PM and clinical outcomes from antibiotic therapies.
\end{abstract}

Keywords: Purulent meningitis, TaqMan Array card, Real-time PCR, Cerebrospinal fluid culture, Detection method

\section{Background}

Purulent meningitis (PM), which is often caused by bacterial or fungal infection, is a serious disease of the central nervous system and particularly life-threatening for children and newborns. The disease is characterized by acute onset, high fever, severe headache, vomiting,

\footnotetext{
*Correspondence: ammsliupeng@163.com; 315234154@qq.com; jiangyq@bmi.ac.cn

${ }^{\dagger}$ Chengna Zhao and Xi Wang contributed equally to this work.

${ }^{2}$ State Key Laboratory of Pathogen and Biosecurity, Beijing Institute of Microbiology and Epidemiology, Beijing, China

${ }^{3}$ Department of Infectious Medicine, Beijing Children's Hospital, Capital Medical University, National Center for Chidren's Health, Beijing, China

${ }^{1}$ Anhui Medical University, Hefei, China

Full list of author information is available at the end of the article
}

stiff neck, and high disability and mortality rates. But in infants and young children, these "classical "signs are often absent, they may be poor feeding, lethargy, disorientation or reduced conscious level. Approximately 10 to $20 \%$ of PM survivors develop post-PM neurological sequelae [1]. The common sequelae of PM include hydrocephalus, cerebral hemorrhage, epilepsy, paralysis, blindness, and mental retardation [2,3]. Thus, timely and accurate treatments are critical to improve PM prognosis, and effective treatments for PM depend on an accurate and rapid identification of the causative bacteria or fungus $[4,5]$.

The commonly recognized gold standard to identify the causative bacteria for PM is the cerebrospinal fluid

(c) The Author(s). 2019 Open Access This article is distributed under the terms of the Creative Commons Attribution 4.0 International License (http://creativecommons.org/licenses/by/4.0/), which permits unrestricted use, distribution, and 
(CSF) culture method [6, 7]. However, the CSF culture method has many limitations. For instance, the procedure is too complex; the time for an affirmative result is too long (usually longer than $48 \mathrm{~h}$ ); the method often fails if patients receive empiric antibiotic therapies $[8,9]$.

The direct Gram staining method can provide results rapidly and confirm a diagnosis of bacterial infection in $60-90 \%$ of patients, and a confirmed diagnosis from Gram staining depends on the bacterial concentration in CSF samples [7]. The Gram staining method may fail when the bacterial concentration is too low in CSF samples, and the sensitivity of the Gram staining method also varies widely for different microorganisms [10]. Although CT may be useful to diagnose PM, a low accessibility to $\mathrm{CT}$ scanners and the requirement of further laboratory tests limit its application [11]. The results of the method of MALDI-TOF MS were usually affected by culture media, cultivation conditions, or incubation times $[12,13]$. A regular PCR combined with gel electrophoresis has a low sensitivity. The sequencing method is usually time-consuming, has a complex protocol, and is expensive [14-16]. Luminex Verigene, a high-throughput platform, can detect multiple pathogens from one sample simultaneously but requires a relatively long time to collect results [17]. In 2015, the United States Food and Drug Administration approved the first multiplex PCR kit (FilmArray ${ }^{\circ}$ system) as an auxiliary diagnostic method to identify causative pathogens of meningitis and encephalitis. The FilmArray ${ }^{\circ}$ system $[18,19]$ can simultaneously detect 14 pathogens (6 bacteria, 7 viruses, and $C$. neoformans/C. gattii) from CSF samples in approximately $1 \mathrm{~h}$. However, the system is very expensive $(\$ 305-\$ 453 /$ sample and \$22-\$32/pathogen) [20, 21].

A TaqMan array card (TAC), which combines the real-time PCR technology and microfluidics highthroughput technology, appears superior to those methods. A TAC has 384 wells on a microfluidic chip and thus can detect up to 48 targeted pathogens simultaneously using a small amount of a sample. The TAC technology has been used to identify respiratory pathogens [22], enteropathogens [23], bioterrorism pathogens [24, 25], neonatal infection [26], and drug resistance mutations [27]. Liu and colleagues compared the performance of a TAC, multiplex real-time quantitative PCR, and the PCR-Luminex platform in the identification of enteric pathogens [28], and they found that the TAC showed the best sensitivity and specificity. TAC assays were used to identify the causative microorganisms of respiratory disease outbreaks in the United States [29]. Although TAC systems have been used successfully to identify pathogens, a comparison of the sensitivity of a TAC versus the CSF culture method to identify pathogens in CSF samples from patients receiving empiric antibiotic treatments is still lacking. Moreover, whether TAC results could indicate
PM severity remains unclear. Here, we aim to fill these knowledge gaps. In the current study, we developed a high-throughput PM-TAC, compared the sensitivity of the PM-TAC versus the CSF culture method to detect pathogens from CSF samples of children with PM after using antibiotics, and explored whether PM-TAC results could indicate PM severity.

\section{Methods}

\section{The design of the PM-TAC}

The PM-TAC targets 21 pathogens (Fig. 1), including 16 bacteria and 5 fungi (Additional file 1: Table S1). The primer and probe sequences for the majority of the targeted pathogens were originally from previous publications except that the sequences for Histoplasma capsulatum and Oidium coccidioides were designed in the current study. A single gene was targeted for each individual pathogen and every target was duplicated. The BLAST from the NCBI database, Clustal, and Primer Express (Life Technologies, Carlsbad, CA) were used to design and evaluate the primer and probe sequences. The sequences were optimized for the universal cycling conditions. All of the primers and probes were validated by real-time PCR assays using positive-control plasmids or pathogen genomic DNA. An off-target DAN template contains DNA template sequences of all the target pathogens on the TAC except the DNA template sequences of one pathogen that is targeted by its specific primer/probe pair. An on-target DNA template contains the DNA template sequences of one pathogen that is targeted by its specific primer/probe pairs. The DNA sequences of primers and probes are described in Additional file 1: Table S1. The universal formula for TAC assay was used. The final concentrations of each primer and probe were $900 \mathrm{nM}$ and $250 \mathrm{nM}$, respectively.

\section{Control plasmid construction}

A long oligonucleotide containing the sequences of primer and probe sequences of all of the targeted pathogens was first synthetized by Sangon Biotech. The oligonucleotide included the forward primer sequences, probe sequences, and the reverse complement of the reverse primer sequences of the 21 targeted pathogens. The detailed design of the oligonucleotide is illustrated in Fig. 2. The oligonucleotide was used as an artificial template [30]. The oligonucleotide was inserted into the pMDTM19-T vector using the pMDTM19-T Vector Cloning Kit (TAKARA). The recombinant pMDTM19-T construct was used as a control plasmid.

\section{Evaluation of the PM-TAC}

A dose effect of the control plasmid on the PM-TAC assay was analyzed. We also prepared an artificial cerebrospinal fluid (ACSF) according to a previous 


\begin{tabular}{|c|c|c|c|c|c|c|c|c|c|}
\hline 11 & & & & & 6 & 7 & 8 & Inlet & Port \\
\hline 24こ & ك5 & 25 & 25 & 25 & ك5 & 5 & 25 & Streptococcus pneumoniae & Streptococcus pneumoniae \\
\hline & ك5 & 2 & 25 & ك5 & ك5 & ك & ك5 & Staphylococcus aureus & Staphylococcus aureus \\
\hline ك5 & ك5 & 25 & 2 & ك5 & ك5 & 2 & ك5 & Escherichia coli & Escherichia coli \\
\hline ك ك21 & ك & ك ك & ك & ك & ك ك & ك ك & ك & $\begin{array}{l}\text { Listeria monocytogenes } \\
\text { Streptococcus agalactiae }\end{array}$ & $\begin{array}{l}\text { Listeria monocytogenes } \\
\text { Streptococcus agalactiae }\end{array}$ \\
\hline ك ك & ك & 与 & 5 & ב & ك & ك & ב & 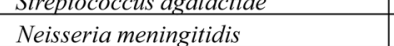 & $\begin{array}{l}\text { Streptococcus agalactiae } \\
\text { Neisseria meningitidis }\end{array}$ \\
\hline & ك5 & ك & 25 & ك5 & ك5 & 2 & ك5 & Mycobacterium tuberculosis complex & Mvcobacterium tuberculosi \\
\hline & ك5 & ك & ك5 & 25 & ك & ك & ك5 & Klebsiella pneumoniae & Klebsiella pneumoniae \\
\hline & 2 & ك & ك & ك & ב & ك & 5 & Staphylococcus epidermidis & Staphylococcus epidermidis \\
\hline ك ك514 & ك & ك & ك & ك & ك & ك5 & ك & $\begin{array}{l}\text { Acinetobacter baumannii } \\
18 \mathrm{~S}\end{array}$ & $\begin{array}{l}\text { Acinetobacter baumannii } \\
18 \mathrm{~S}\end{array}$ \\
\hline & ك & ك & ك & 2 & ك & ك & ك5 & $\mathrm{PhHV}$ & $\mathrm{PhHV}$ \\
\hline 125 & ك & ك & ك & ك & ك ك & ك & ك & RNase P & RNase P \\
\hline ك ك & ك & ك & 与 & 与 & ك & ك & ك & $\begin{array}{l}\text { Haemophilus influenzzee } \\
\text { Psendomonas aeruginosa }\end{array}$ & $\begin{array}{l}\text { Haemophilus influenzae } \\
\text { Pseudomonas aeruginosa }\end{array}$ \\
\hline & ك5 & ك & 25 & ك5 & ك5 - 2 r & 25 & ك5 & Streptococcus suis serotype 2 & Streptococcus suis serotype 2 \\
\hline & ك & ك ك & 与 & ك5 & ك.5 & ك & ك5 & Salmonella spp. & Salmonella spp. \\
\hline & & & 2 & & ك & & & Mycoplasma pneumoniae & Mycoplasma pneumoniae \\
\hline$C_{-1}$ & 5 & ك & 2 2 & ك & ك ك & ك & ك5 & Leptospira & Leptospira \\
\hline & 2 & 2 & ל & ك 5 & ك & ك & 50 & Cryptococcus neoformans & Cryptococcus neoformans \\
\hline & & & & & & & 5 & Aspergillus nidulans & Aspergillus nidulans \\
\hline & & & 与 & $\tau$ & ᄃ & 5 & ك & $\begin{array}{l}\text { Candida a albicans } \\
\text { Histoplasma casulatum }\end{array}$ & $\begin{array}{l}\text { Candida albicans } \\
\text { Histoplasma capsulatum }\end{array}$ \\
\hline & & & & & & & & & um coccidioides \\
\hline
\end{tabular}

Fig. 1 Configuration of the Purulent Meningitis-TaqMan Array Card

description (43). To estimate the accuracy and LOD of the PM-TAC, the control plasmid was added to the ACSF. To determine the accuracy, two doses of the control plasmid were used for each targeted pathogen: a low dose, which was the LOD estimated from the real-time PCR assay, and a high dose, which was a dose of 100 times of the LOD. To estimate the intra-assay variations, 8 replicates were used for each dose. To estimate inter-assay variations, 4 replicates were used for each dose and 5 batches of PM-TAC were used, and the assay for each batch was conducted on different days. To determine the LOD of the PM-TAC, several doses of the control plasmid (5 copies $/ \mu \mathrm{L}-100$ copies $/ \mu \mathrm{L}$ ) for each targeted pathogen were tested and 10 replicates were used for each dose. LOD of the PM-TAC was defined as the lowest concentration of the control plasmid that could be detected in all of the 10 replicated samples for each targeted pathogen. The sensitivity and specificity of the PM-TAC were estimated using ACSF spiked with a pure culture of Streptococcus pneumoniae, Streptococcus agalactiae, Staphylococcus aureus, Listeria monocytogenes, Staphylococcus epidermidis, Pseudomonas aeruginosa, Acinetobacter baumannii, Escherichia coli, Klebsiella pneumoniae, or Cryptococcus neoformans. Twenty replicates were used for each spiked ACSF. The volume of each spiked ACSF was $500 \mu \mathrm{L}$. Total nucleic acid extraction method for clinical CSF samples was used for the spiked ACSF samples. A real-time PCR was used as a gold standard to estimate the sensitivity and specificity.

\section{Cerebrospinal fluid samples}

CSF samples were obtained from the Department of Infectious Disease of Beijing Children's Hospital (Additional file 1: Table S2). The diagnosis of PM followed the WHO diagnostic guidelines. WHO writes that a suspected PM case with CSF examination showing at least one of the following: turbid appearance; leukocytosis (> 100 cells $\left./ \mathrm{mm}^{3}\right)$; leukocytosis $\left(10-100\right.$ cells $\left./ \mathrm{mm}^{3}\right)$ AND either elevated protein $(>100 \mathrm{mg} / \mathrm{dL})$ or decreased glucose $(<40 \mathrm{mg} / \mathrm{dL})$. A total of 32 children with PM were selected with a representative cross-section of the patient population in the Department of Infectious Disease of Beijing Children's Hospital. Of the 32 patients, 13 showing positive CSF culture before receiving antibiotics but negative after receiving antibiotics, 2 showing positive CSF culture before antibiotic therapies and

Fig. 2 The design the oligonucleotide inserted in the control plasmid. The oligonucleotide includes the sequences of primers and probes of the 21 targeted pathogens. F: forward primer; P: probe; Rc: the reverse complement of reverse primer. F1 is referring to the forward primer sequence of pathogen 1; F2 is referring to the forward primer sequence of pathogen 2; P1 is referring to the probe sequence of pathogen 1 
remaining positive after the antibiotic therapies, 17 showing negative CSF culture before and after antibiotic therapies. All of the 32 children presented at least one typical clinical symptoms of PM, such as intermittent fever, headache, anterior fontanelle full, vomiting, convulsions, mental changes, altered consciousness, and meningeal irritation. Ten children without PM were also selected to evaluate the specificity of the PM-TAC. The ten children presented fever and similar neurologic symptoms such as meningeal irritation sign. In order to rule out PM, CSF examination was done. And CSF examination of this ten children was normal according to the WHO guidelines.

\section{Total nucleic acid extraction}

ACSF spiked with different concentrations of Streptococcus pneumoniae or Cryptococcus neoformans culture was used to optimize the nucleic acid extraction method. The modified protocol of QIAamp cador pathogen Mini Kit was used. Briefly, $250 \mu \mathrm{L}$ of each sample was added to the pathogen lysis tube, which contained $0.2 \mathrm{~g}$ glass beads with a particle size of $450 \mu \mathrm{m}$ to $600 \mu \mathrm{m}$ and $0.2 \mathrm{~g}$ glass beads with a particle size of $100 \mu \mathrm{m}$ (Sigma, St. Louis, MO). The lysis tube was centrifuged for $5 \mathrm{~min}$ at $14,000 \times \mathrm{g}$, and then $200 \mu \mathrm{L}$ of the supernatant was transferred to a $1.5 \mathrm{~mL}$ microcentrifuge tube containing $20 \mu \mathrm{L}$ QIAGEN Protease K. A total of $400 \mu \mathrm{L}$ lysis buffer was added into the pathogen lysis tube to re-suspend the pellet. The pathogen lysis was then extracted as the manual. Total nucleic acid was eluted in $100 \mu \mathrm{L}$ AVE buffer. A blank control $\left(\mathrm{H}_{2} \mathrm{O}\right)$ was included for each batch of extraction to monitor laboratory contaminations. If the blank control showed positive on the PM-TAC assay, the entire batch of total nucleic acid was discarded.

\section{PM-TAC assay}

A total of $50 \mu \mathrm{L}$ total nucleic acid was used to prepare a reaction mixture (a total volume of $100 \mu \mathrm{L}$ ) for the PM-TAC assay. The ABI master mix (Art.No.4440038) was used. The PM-TAC has 8 channels, 7 for samples and one for a blank control. The reaction mixture was loaded into the inlet port of each channel. The PM-TAC was then centrifuged twice at $1200 \mathrm{rpm}$ for $1 \mathrm{~min}$ and sealed. After the centrifugation, the inlet ports were removed according to the manufacturer's instruction. The PM-TAC was analyzed on the Vii A 7 real-time PCR system (Life Technologies) using the following PCR cycling conditions: $50{ }^{\circ} \mathrm{C}$ for $2 \mathrm{~min}$ and $95^{\circ} \mathrm{C}$ for $10 \mathrm{~min}, 40$ cycles of $95^{\circ} \mathrm{C}$ for $15 \mathrm{~s}$ and $60^{\circ} \mathrm{C}$ for $45 \mathrm{~s}$. A sample was considered positive for the targeted pathogen when the cycle threshold (CT) value was $<38.0$ for the PM-TAC assay and the extraction blank control was negative.

\section{Ethics statement}

The study protocols were approved by the Institutional Review Boards of the Institute of Microbiology and Epidemiology and Capital Medical University of China. Written informed consent was obtained from a parent or guardian prior to collect CSF from the children.

\section{Results}

\section{Performance of each assay on 96-well plate using} individual real-time PCR

Real-time PCR was first performed to validate the primers and probes using a 96-well plate. The control plasmid was used as the template in the real-time PCR for the validation. For each primer and probe pair, the $\mathrm{CT}$ value and the template concentration showed a significant linear correlation. For the 21 targeted pathogens, linear correlation coefficient $\left(R^{2}\right)$ ranged from 0.995 to 1.0; PCR efficiency ranged from 82.8 to $96.7 \%$; LOD ranged from 3.125 copies $/ \mu \mathrm{L}$ to 100 copies $/ \mu \mathrm{L}$ (Table 1). The cross-reactivity of the primers and probes was also tested on 96-well plates. Off-target DNA templates, which do not contain the DNA temple sequence

Table 1 Evaluation of primers and probes using real-time PCR

\begin{tabular}{|c|c|c|c|}
\hline & $\mathrm{R}^{2}$ & $\begin{array}{l}\text { Efficiency } \\
(\%)\end{array}$ & $\begin{array}{l}\text { LOD } \\
\text { (copies/ } \mu \mathrm{L})\end{array}$ \\
\hline Streptococcus pneumoniae & 1.0 & 90.23 & 100 \\
\hline Staphylococcus aureus & 0.998 & 87.12 & 25 \\
\hline Escherichia coli & 0.999 & 90.12 & 100 \\
\hline Listeria monocytogenes & 1.0 & 94.42 & 25 \\
\hline Streptococcus agalactiae & 0.997 & 85.42 & 25 \\
\hline Neisseria meningitidis & 1.0 & 96.46 & 25 \\
\hline $\begin{array}{l}\text { Mycobacterium tuberculosis } \\
\text { complex }\end{array}$ & 0.999 & 97.59 & 25 \\
\hline Leptospira & 0.999 & 84.55 & 6.25 \\
\hline Mycoplasma pneumoniae & 0.999 & 89.6 & 10 \\
\hline Oidium coccidioides & 0.999 & 89.78 & 3.125 \\
\hline Histoplasma capsulatum & 1.0 & 92.76 & 6.25 \\
\hline Cryptococcus neoformans & 0.999 & 92.75 & 6.25 \\
\hline Staphylococcus epidermidis & 0.997 & 92.75 & 100 \\
\hline Acinetobacter baumannii & 0.995 & 85.81 & 100 \\
\hline Streptococcus suis serotype 2 & 0.999 & 85.0 & 12.5 \\
\hline Pseudomonas aeruginosa & 1.0 & 85.36 & 50 \\
\hline Candida albicans & 0.997 & 82.8 & 5 \\
\hline Haemophilus influenzae & 0.998 & 94.1 & 5 \\
\hline Klebsiella pneumoniae & 0.999 & 96.7 & 3.125 \\
\hline Aspergillus nidulans & 0.997 & 95.0 & 3.125 \\
\hline Salmonella spp. & $\begin{array}{l}0.998^{\mathrm{a}} / \\
0.995^{\mathrm{b}}\end{array}$ & $\begin{array}{l}90.0^{\mathrm{a}} / \\
92.1^{\mathrm{b}}\end{array}$ & $10^{a} / 25^{b}$ \\
\hline
\end{tabular}

Salmonella spp.in this study included Typhoid bacillus (a) and Salmonella paratyphi $A$ (b) 
for a specific primer/probe pair, were added into reaction mix to analyze the cross-reactivity of each primer and probe pair. The amplification showed a very high specificity (Fig. 3). Only the on-target DNA template, which only contains the DNA template sequence for a specific primer/probe pair, was amplified by each specific primer and probe pair (Fig. 3). ACSF spiked with different concentrations of Streptococcus pneumoniae or Cryptococcus neoformans culture was used to evaluate the nucleic acid extraction method. ACSF had no effects on CT values, indicating that the matrix inhibitors in ACSF, such as divalent salts and urea, appeared to be removed effectively during total nucleic acid extraction (Fig. 4).

\section{Performance for evaluation of PM-TAC}

We also evaluated the primers and probes in the PM-TAC assay. ACSF was spiked with the control plasmid first, and then the ACSF containing the control plasmid was used for the validation of the primers and probes in the PM-TAC assay. In the PM-TAC assay, for the 21 targeted pathogens, the linear correlation coefficient $\left(R^{2}\right)$ ranged from 0.99 to 0.999 ; PCR efficiency was greater than $88.469 \%$; LOD ranged from 5 copies/reaction to 50copies/reaction except Streptococcus pneumoniae with a LOD of 100 copies/reaction. The intra-assay variation of the PM-TAC assay at high and low concentration of the template was $\leq 1.84 \%$ and $\leq 4.45 \%$, respectively, and the inter-assay variation at the high and low concentration of the template was $\leq 5.21 \%$ and $\leq 6.81 \%$, respectively, for all of the target pathogens (Additional file 1: Table S3). We evaluated the sensitivity and specificity of the PM-TAC using ACSF spiked with the targeted pathogens. The overall sensitivity and specificity were 95 and $96 \%$, respectively (Table 2 ).

\section{Comparison of PM-TAC versus the CSF culture method}

Only two of the 15 CSF samples showing positive CSF culture before antibiotic therapies remained positive CSF culture after the antibiotic therapies. In contrast to the CSF culture results, 8 of the 15 samples showed positive from the PM-TAC assay after antibiotic therapies (Table 3). We conducted 16SrDNA PCR sequencing to confirm the PM-TAC results. The results of PCR/ sequencing and PM-TAC were consistent (Table 3).

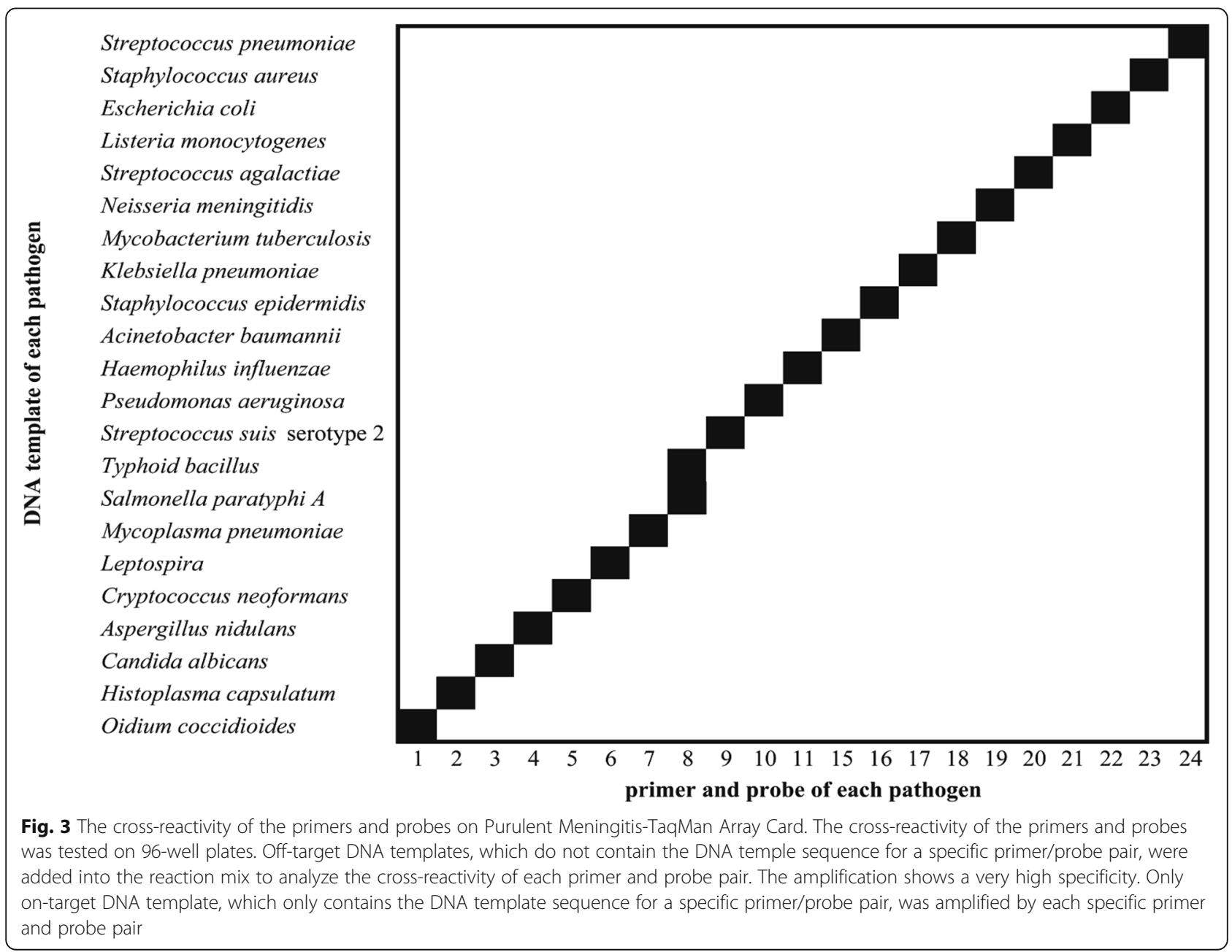




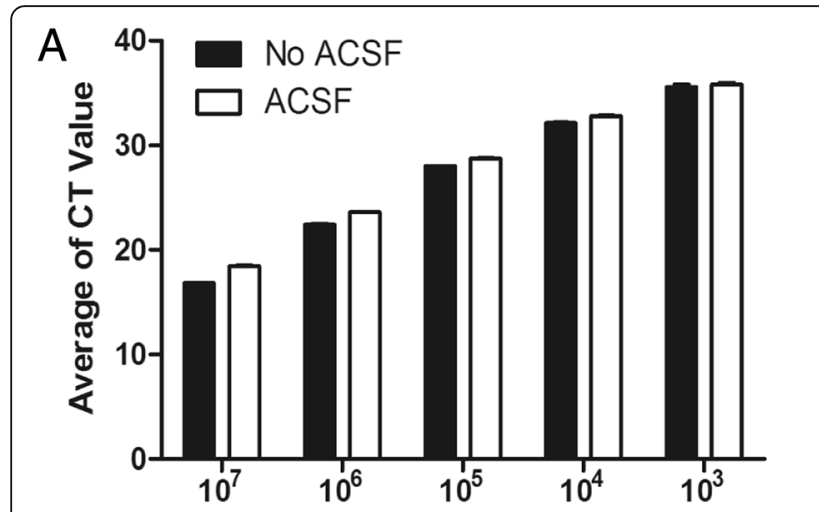

Number of Spiked Streptococcus pneumoniae (CFU)

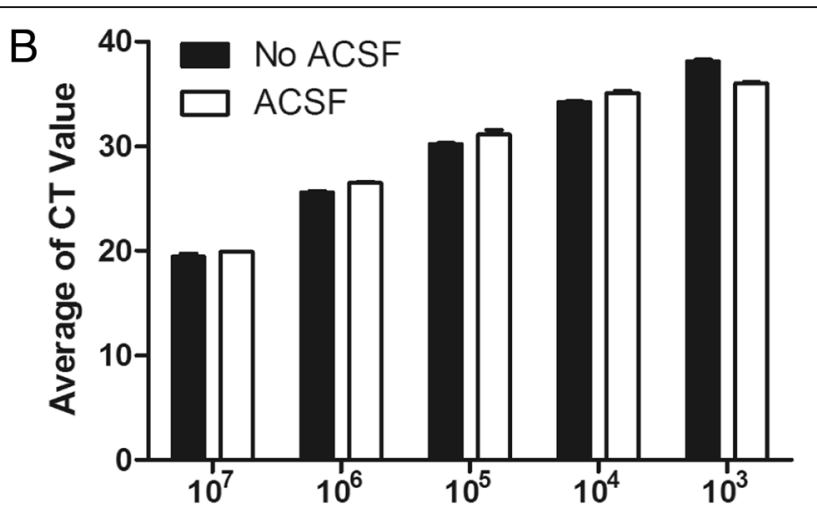

Number of Spiked Cryptococuus neofomans (CFU)

Fig. 4 Analysis of matrix inhibition of the extraction of artificial cerebrospinal fluid. a. ACSF spiked with Streptococcus pneumoniae. b. ACSF spiked with Cryptococcus neoformans. Different concentrations of the bacteria were added in the ACSF. ACSF had no significant effects on the cycle threshold values

We used 17 CSF samples of PM showing negative CSF culture before and after antibiotic therapies to further evaluate the sensitivity of the PM-TAC (Additional file 1: Table S4). Of the 17 samples, one was positive for Neisseria meningitidis from the PM-TAC assay (confirmed by PCR sequencing) (Additional file 1: Table S4). Notably, one sample was negative from both CSF culture and PM-TAC assay but positive for Enterococcus faecium from the $\mathrm{PCR} /$ sequencing analysis (Additional file 1: Table S4). The reason for this inconsistency was that the pathogen Enterococcus faecium was not included on the PM-TAC in this study. To further evaluate the specificity of the PM-TAC, we used 10 CSF samples from patients without central nervous system infection. The 10 CSF samples showed negative from both the PM-TAC assay and the CSF culture method (Additional file 1: Table S5).
These data demonstrated that the specificity of the PM-TAC was $100 \%$.

\section{The association of positive PM-TAC results and PM severity}

To evaluate whether PM-TAC results could indicate PM severity, we analyzed the cycle threshold (CT) of PM-TAC assay and patient clinical presentations. A lower CT of PM-TAC assay represents higher pathogen loads in samples. We compared CT and clinical presentation in patients showing positive for the same pathogen (Table 4). For the two patients showing positive Streptococcus pneumoniae in CSF, the patient with a lower CT (34.0) presented intermittent fever for 4 months, higher CSF cell count, and bilateral subdural effusion and left subdural empyema, whereas the patient with a high CT (37.72) did not present those complications. Similarly, the patient

Table 2 Sensitivity and specificity of the PM-TAC assay using ACSF spiked with targeted pathogens

\begin{tabular}{|c|c|c|c|c|}
\hline \multirow[b]{2}{*}{ Targeted Pathogen } & \multicolumn{4}{|l|}{ Numbers of samples } \\
\hline & IRTP + and PM-TAC + & IRTP + and PM-TAC - & IRTP - and PM-TAC + & IRTP - and PM-TAC - \\
\hline Streptococcus pneumoniae & 18 & 2 & 0 & 10 \\
\hline Streptococcus agalactiae & 19 & 1 & 0 & 10 \\
\hline Staphylococcus aureus & 20 & 0 & 1 & 9 \\
\hline Listeria monocytogenes & 19 & 1 & 1 & 9 \\
\hline Staphylococcus epidermidis & 18 & 2 & 0 & 10 \\
\hline Pseudomonas aeruginosa & 19 & 1 & 2 & 10 \\
\hline Klebsiella pneumoniae & 20 & 0 & 0 & 9 \\
\hline Acinetobacter baumannii & 20 & 0 & 0 & 10 \\
\hline Escherichia coli & 20 & 0 & 0 & 10 \\
\hline Cryptococcus neoformans & 17 & 3 & 0 & 10 \\
\hline Total & Sensitivity $=95 \%$ & & Specificity $=96 \%$ & \\
\hline
\end{tabular}


Table 3 Comparison of the PM-TAC assay versus the CSF culture method

\begin{tabular}{|c|c|c|c|c|c|}
\hline \multirow{2}{*}{$\begin{array}{l}\text { Patients } \\
\text { No. }\end{array}$} & \multicolumn{2}{|l|}{ CSF culture result } & \multirow{2}{*}{$\begin{array}{l}\text { PM-TAC assay result } \\
\text { After antibiotic therapies }\end{array}$} & \multirow[t]{2}{*}{ Concordance } & \multirow[t]{2}{*}{$\mathrm{PCR} /$ sequencing result } \\
\hline & Before antibiotic therapies & After antibiotic therapies & & & \\
\hline 001 & Streptococcus pneumoniae & Negative & Negative & Yes & Negative \\
\hline 002 & Streptococcus pneumoniae & Negative & Streptococcus pneumoniae & No & Streptococcus pneumoniae \\
\hline 003 & Klebsiella pneumoniae & Klebsiella pneumoniae & Klebsiella pneumoniae & Yes & - \\
\hline 004 & Haemophilus influenzae & Negative & Negative & Yes & Negative \\
\hline 005 & Klebsiella pneumoniae & Negative & Klebsiella pneumoniae & No & Klebsiella pneumoniae \\
\hline 006 & Escherichia coli & Negative & Escherichia coli & No & Escherichia coli \\
\hline 007 & Salmonella spp & Negative & Negative & Yes & Negative \\
\hline 008 & Baumanii & Baumanii & Baumanii & Yes & - \\
\hline 009 & Streptococcus pneumoniae & Negative & Negative & Yes & Negative \\
\hline 010 & Streptococcus pneumoniae & Negative & Negative & Yes & Negative \\
\hline 011 & Streptococcus pneumoniae & Negative & Streptococcus pneumoniae & No & Streptococcus pneumoniae \\
\hline 012 & Escherichia coli & Negative & Escherichia coli & No & Escherichia coli \\
\hline 013 & Escherichia coli & Negative & Escherichia coli & No & Escherichia coli \\
\hline 014 & Streptococcus pneumoniae & Negative & Negative & Yes & Negative \\
\hline 015 & Listeria monocytogenes & Negative & Negative & Yes & Negative \\
\hline
\end{tabular}

with a low CT (30.72) of Klebsiella pneumoniae presented more severe symptoms and complications, such as cerebral ventricle inflammation, subdural effusion and empyema, and hearing loss, compared with the patient with a higher CT (34.49), who only presented subdural effusion. Consistently, in the three patients showing positive Escherichia coli from the PM-TAC assay, the one with the lowest CT (19.71) presented recurrent seizures and subdural empyema and with mass effect and developed hemiplegic paralysis, whereas the other two patients showed high CTs (33.34 and 33.59) presented milder complications and no post-PM sequelae (Table 4).

\section{Discussion}

In the current study, we developed a PM-TAC and optimized the PM-TAC assay. Our PM-TAC showed a LOD of 5 to 50 copies/reaction, except Streptococcus pneumoniae with a LOD of 100 copies/reaction, a sensitivity of $95 \%$, and a specificity of $96 \%$. These performance parameters are similar to the findings from a previous study [11]. Compared with the CSF culture method, which usually has a sensitivity of $81.3 \%$, our PM-TAC was more sensitive $[7,10]$. In addition to the superior sensitivity, our PM-TAC assay produced results fairly faster (in $3 \mathrm{~h}$ ) at a lower cost $(\$ 126 /$ sample) than the next generation sequencing (NGS) method (72 $\mathrm{h}$ of the assay time and $\$ 500 /$ sample) [14]. Although the NGS technology has been improved continuously, it remains to be tedious and requires comprehensive bioinformatic analyses. All of those disadvantages of the NGS method limit its application in clinical practice. In contrast to the NGS method, it only took $3 \mathrm{~h}$ to collect results from our

Table 4 The pathogen load in CSF samples and the severity of PM

\begin{tabular}{|c|c|c|c|c|}
\hline $\begin{array}{l}\text { Patients } \\
\text { No. }\end{array}$ & Pathogen & $\begin{array}{l}\mathrm{CT} \\
\text { value }\end{array}$ & Complications & Sequelae \\
\hline 002 & $\begin{array}{l}\text { Streptococcus } \\
\text { pneumoniae }\end{array}$ & 34.0 & Bilateral subdural effusion and left subdural empyema & None \\
\hline 011 & $\begin{array}{l}\text { Streptococcus } \\
\text { pneumoniae }\end{array}$ & 37.72 & None & None \\
\hline 003 & Klebsiella pneumoniae & 30.72 & $\begin{array}{l}\text { Subdural effusion and empyema, cerebral ventricle inflammation, } \\
\text { hearing loss }\end{array}$ & Hearing loss \\
\hline 005 & Klebsiella pneumoniae & 34.49 & Subdural effusion & None \\
\hline 006 & Escherichia coli & 19.71 & Subdural empyema with mass effect & $\begin{array}{l}\text { Hemiplegic paralysis recurrent } \\
\text { seizures }\end{array}$ \\
\hline 012 & Escherichia coli & 33.34 & Subdural effusion & None \\
\hline 013 & Escherichia coli & 33.59 & Hydrocephalus & None \\
\hline
\end{tabular}


PM-TAC assay. Liu and colleagues have shown that the cost of TAC assay is much lower than that of ELISA and other methods [28] The estimated average cost of our PM-TAC assay for each targeted pathogen was approximately $\$ 6$ and $\$ 144$ for a whole panel ( $\$ 6$ x [21 PM-associated pathogens +3 controls] $=\$ 144$ ), which appears affordable for economically underdeveloped regions and countries.

Compared with the CSF culture method, our PM-TAC assay was particularly more sensitive to detect pathogens after empiric antibiotic therapies. The positive rate of our PM-TAC was $53.3 \%(8 / 15)$, whereas it was only $13.3 \%(2 / 15)$ for the CSF culture method for CSF samples collected after empiric antibiotic therapies. These results indicate substantial clinical significance. The PM-TAC assay allows for detection of these pathogens which is independent of the use of antibiotics. The assay can then be used to assess the efficacy of antibiotic therapy in clearing the pathogen and the infection. Previous studies have demonstrated that the rate of inappropriate antibiotic use in the hospital setting is 30 to $50 \%$ because of the lacking an accurate identification of the causative bacteria $[31,32]$. Every pathogen is sensitive to the specific antibiotics. The inappropriate antibiotic use before the pathogen was identified could induce drug resistant in bacteria. To be clinically effective, antibiotics that are specifically targeting the causative bacteria should be prescribed at the proper dosage.

In addition, we found that the $\mathrm{CT}$ of a pathogen from the PM-TAC assay appeared to indicate PM severity. Primary infections are usually pathogenic specific, and thus a pathogen load is associated with the infection severity. Our findings suggest that the PM-TAC assay could provide an effective reference to guide the therapeutic strategies for PM. For example, clinicians could adjust the dosage of antibiotic treatments bases on the PM-TAC results. Our PM-TAC system also allows multiplex detection. According to the clinical experiences of pediatricians, most cases of PM are caused by a single pathogen. In our current study, the 15 clinical CSF samples also showed a single-pathogen infection, which confirmed the clinical experiences.

There are limitations in our current study. There was a small sample size indeed in this study due to the difficulty to collect enough CSF in children clinically. Because many clinical examinations were performed so almost all cerebrospinal fluid were used up and this reduced greatly the sample size. Although the sample size was small, it could reflect a very meaningful phenomenon. Fortunately, we constructed simulated CSF samples being close to the clinical CSF sample based on previously reported studies [33], which made up for the small sample size. Moreover, we are also making efforts to collect new CSF samples from hospitals, but it will take a long time, and with the accumulation of sample size of CSF, we plan to do more in-depth related research in the future. The cost of PM-TAC is still prohibitively expensive for resource poor settings although it is cheaper compared with other molecular diagnostic techniques. Actually, the main cost is the microfluidic chip and at present, microfluidic versions have great potential applications in all aspects and have attracted much attention. At the same time, the production technology of microfluidic plate is developing rapidly. When the material and technology of TAC break through, the cost of this method will be further reduced. In addition, we are also increasing the number of pathogen detected, so that the detection cost of each pathogen will be lower. All of the targeted pathogens on the PM-TAC were selected mainly based on common clinical experiences. Therefore, the PM-TAC is unable to identify previously unidentified pathogens whereas the NGS method could. We will continuously update and expand the targeted pathogen panel on the PM-TAC following the most updated literature. Although the evolutionarily conserved domains were selected to target the pathogens, mutations in the targeted gene may cause false negative results because of the high specificity of the minor groove binder probes. In general, pathogenic bacteria and fungi have a low mutation rate, whereas virus often mutate quickly. Our future study will take gene mutations into consideration when we design a PM-TAC.

\section{Conclusions}

The PM-TAC in this study can detect 21 PM-associated pathogens in $3 \mathrm{~h}$ and showed a higher sensitivity than the CSF culture method particularly for CSF samples collected after empiric antibiotic therapies. The CT of a pathogen from the PM-TAC assay, which represents a pathogen concentration or load in CSF samples, indicated PM severity. Thus, the PM-TAC may be a promising tool for an accurate and rapid diagnosis of PM and thus facilitate a timely antibiotic treatment to improve PM prognosis.

\section{Additional file}

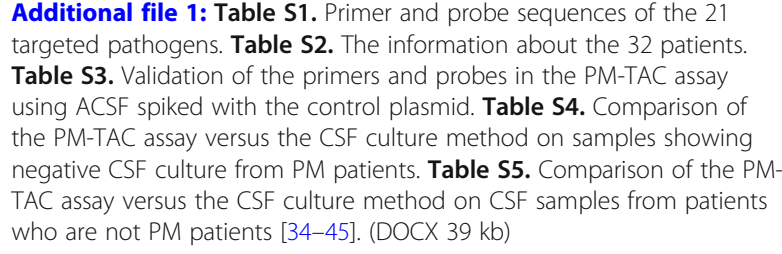

Additional file 1: Table S1. Primer and probe sequences of the 21 targeted pathogens. Table S2. The information about the 32 patients. Table S3. Validation of the primers and probes in the PM-TAC assay using ACSF spiked with the control plasmid. Table S4. Comparison of the PM-TAC assay versus the CSF culture method on samples showing negative CSF culture from PM patients. Table S5. Comparison of the PMTAC assay versus the CSF culture method on CSF samples from patients who are not PM patients [34-45]. (DOCX 39 kb)

\section{Abbreviations}

ACSF: artificial cerebrospinal fluid; CNS: central nervous system; CSF: conventional cerebrospinal fluid; CT: cycle threshold; NGS: the next generation sequencing; PM: Purulent meningitis; PM-TAC: purulent meningitis-TaqMan array card; TAC: TaqMan array card 


\section{Acknowledgements}

Not applicable.

\section{Funding}

This work was supported by by Beijing Natural Science Foundation (7172155), the National Natural Science Foundation of China (81772144) and the Chinese State Key Project Specialized for Infectious Diseases (2018ZX10711001-003). The funders had no role in study design, data collection and analysis, decision to publish, or preparation of the manuscript.

\section{Availability of data and materials}

The datasets are available by request to the corresponding author.

\section{Authors' contributions}

CNZ and PL drafted the manuscript and designed the study with YQJ and GL. CNZ, XW, CZ, BL and HBJ performed laboratory work. LHM, HJ, and YLZ analyzed the data. All authors read and approved the final manuscript.

\section{Ethics approval and consent to participate}

The study protocols were approved by the Institutional Review Boards of the Institute of Microbiology and Epidemiology and Capital Medical University of China. Written informed consent was obtained from a parent or guardian prior to collect CSF from the children.

\section{Consent for publication}

Not applicable. The manuscript does not contain personal details.

\section{Competing interests}

The authors declare that they have no competing interests.

\section{Publisher's Note}

Springer Nature remains neutral with regard to jurisdictional claims in published maps and institutional affiliations.

\section{Author details \\ ${ }^{1}$ Anhui Medical University, Hefei, China. ${ }^{2}$ State Key Laboratory of Pathogen and Biosecurity, Beijing Institute of Microbiology and Epidemiology, Beijing, China. ${ }^{3}$ Department of Infectious Medicine, Beijing Children's Hospital, Capital Medical University, National Center for Chidren's Health, Beijing, China. ${ }^{4}$ Shunyi District Center for Disease Control and Prevention, Beijing, China. ${ }^{5}$ Chest Hospital of Xinjiang, Urumqi, China.}

\section{Received: 31 October 2018 Accepted: 27 February 2019}

\section{Published online: 28 March 2019}

\section{References}

1. Namani SA, Koci RA, Qehaja-Bucaj E, Ajazaj-Berisha L, Mehmeti M. The epidemiology of bacterial meningitis in Kosovo. J Infect Dev Ctries. 2014; 8(7):823-30

2. Benjamin DK, DeLong E, Cotten CM, Garges HP, Steinbach WJ, Clark RH. Mortality following blood culture in premature infants: increased with gramnegative bacteremia and candidemia, but not gram-positive bacteremia. J Perinatol. 2004;24(3):175-80.

3. Stoll BJ, Hansen NI, Adams-Chapman I, Fanaroff AA, Hintz SR, Vohr B, Higgins RD, H. National Institute of Child, N. Human Development Neonatal Research, Neurodevelopmental and growth impairment among extremely low-birth-weight infants with neonatal infection. JAMA. 2004:292(19):2357-65.

4. Stoll BJ, Hansen N, Fanaroff AA, Wright LL, Carlo WA, Ehrenkranz RA, Lemons JA, Donovan EF, Stark AR, Tyson JE, et al. To tap or not to tap: high likelihood of meningitis without sepsis among very low birth weight infants. Pediatrics. 2004;113(5):1181-6.

5. Garges HP, Moody MA, Cotten CM, Smith PB, Tiffany KF, Lenfestey R, Li JS, Fowler VG Jr, Benjamin DK Jr. Neonatal meningitis: what is the correlation among cerebrospinal fluid cultures, blood cultures, and cerebrospinal fluid parameters? Pediatrics. 2006;117(4):1094-100.

6. Cunha BA. The clinical and laboratory diagnosis of acute meningitis and acute encephalitis. Expert Opin Med Diagn. 2013;7(4):343-64.

7. Wu HM, Cordeiro SM, Harcourt BH, Carvalho M, Azevedo J, Oliveira TQ, Leite MC, Salgado K, Reis MG, Plikaytis BD, et al. Accuracy of real-time PCR, gram stain and culture for Streptococcus pneumoniae, Neisseria meningitidis and Haemophilus influenzae meningitis diagnosis. BMC Infect Dis. 2013;13:26.

8. Nigrovic LE, Malley R, Macias CG, Kanegaye JT, Moro-Sutherland DM, Schremmer RD, Schwab SH, Agrawal D, Mansour KM, Bennett JE, et al. Effect of antibiotic pretreatment on cerebrospinal fluid profiles of children with bacterial meningitis. Pediatrics. 2008;122(4):726-30.

9. Ahmadi K, Akya A, Numanpour B, Salimi A, Veisi-Raigani A. Frequency of Streptococcus pneumoniae infection in patients with suspected meningitis in imam Reza Hospital of Kermanshah in the west of Iran. Iran J Microbiol. 2015;7(1):12-7.

10. Brouwer MC, Tunkel AR, van de Beek D. Epidemiology, diagnosis, and antimicrobial treatment of acute bacterial meningitis. Clin Microbiol Rev. 2010;23(3):467-92

11. Onyango CO, Loparev V, Lidechi S, Bhullar V, Schmid DS, Radford K, Lo MK, Rota P. Johnson BW, Munoz J, et al. Evaluation of a TaqMan Array card for detection of central nervous system infections. J Clin Microbiol. 2017;55(7):2035-44.

12. Singhal N, Kumar M, Kanaujia PK, Virdi JS. MALDI-TOF mass spectrometry: an emerging technology for microbial identification and diagnosis. Front Microbiol. 2015;6:791.

13. Marin M, Arroyo R, Espinosa-Martos I, Fernandez L, Rodriguez JM. Identification of emerging human mastitis pathogens by MALDI-TOF and assessment of their antibiotic resistance patterns. Front Microbiol. 2017;8:1258.

14. Wilson MR, Naccache SN, Samayoa E, Biagtan M, Bashir H, Yu G, Salamat SM, Somasekar S, Federman S, Miller S, et al. Actionable diagnosis of neuroleptospirosis by next-generation sequencing. N Engl J Med. 2014; 370(25):2408-17.

15. Hamdi S, Rousseau GM, Labrie SJ, Kourda RS, Tremblay DM, Moineau S, Slama KB. Characterization of five Podoviridae phages infecting Citrobacter freundii. Front Microbiol. 2016;7:1023.

16. Zhang $Y$, Zhao F, Kong M, Wang S, Nan L, Hu B, Olszewski MA, Miao Y, Ji D, Jiang $W$, et al. Validation of a high-throughput multiplex genetic detection system for helicobacter pylori identification, quantification, virulence, and resistance analysis. Front Microbiol. 2016;7:1401.

17. Walker T, Dumadag S, Lee CJ, Lee SH, Bender JM, Cupo Abbott J, She RC. Clinical impact of laboratory implementation of Verigene BC-GN microarraybased assay for detection of gram-negative bacteria in positive blood cultures. J Clin Microbiol. 2016:54(7):1789-96.

18. Leber AL, Everhart K, Balada-Llasat JM, Cullison J, Daly J, Holt S, Lephart P, Salimnia H, Schreckenberger PC, DesJarlais S, et al. Multicenter Evaluation of BioFire FilmArray Meningitis/Encephalitis Panel for Detection of Bacteria, Viruses, and Yeast in Cerebrospinal Fluid Specimens. J Clin Microbiol. 2016;54(9):2251-61.

19. Naccache SN, Lustestica M, Fahit M, Mestas J, Dien Bard J. One year in the life of a rapid syndromic panel for meningitis/encephalitis: a pediatric tertiary care Facility's experience. J Clin Microbiol. 2018;56(5).

20. Soucek DK, Dumkow LE, VanLangen KM, Jameson AP. Cost justification of the BioFire FilmArray meningitis/encephalitis panel versus standard of Care for Diagnosing Meningitis in a community hospital. J Pharm Pract. 2017. https://doi.org/10.1177/0897190017737697.

21. Graf EH, Farquharson MV, Cardenas AM. Comparative evaluation of the FilmArray meningitis/encephalitis molecular panel in a pediatric population. Diagn Microbiol Infect Dis. 2017;87(1):92-4.

22. Kodani M, Yang G, Conklin LM, Travis TC, Whitney CG, Anderson LJ, Schrag SJ, Taylor TH Jr, Beall BW, Breiman RF, et al. Application of TaqMan lowdensity arrays for simultaneous detection of multiple respiratory pathogens. J Clin Microbiol. 2011:49(6):2175-82

23. Liu J, Gratz J, Amour C, Kibiki G, Becker S, Janaki L, Verweij JJ, Taniuchi M, Sobuz SU, Haque R, et al. A laboratory-developed TaqMan Array card for simultaneous detection of 19 enteropathogens. J Clin Microbiol. 2013;51(2):472-80.

24. Rachwal PA, Rose HL, Cox V, Lukaszewski RA, Murch AL, Weller SA. The potential of TaqMan Array cards for detection of multiple biological agents by real-time PCR. PLoS One. 2012;7(4):e35971.

25. Weller SA, Cox V, Essex-Lopresti A, Hartley MG, Parsons TM, Rachwal PA, Stapleton HL, Lukaszewski RA. Evaluation of two multiplex real-time PCR screening capabilities for the detection of Bacillus anthracis, Francisella tularensis and Yersinia pestis in blood samples generated from murine infection models. J Med Microbiol. 2012;61(Pt 11):1546-55.

26. Diaz MH, Waller IL, Napoliello RA, Islam MS, Wolff BJ, Burken DJ, Holden RL, Srinivasan V, Arvay M, McGee L, et al. Optimization of multiple pathogen detection using the TaqMan Array card: application for a population-based study of neonatal infection. PLoS One. 2013;8(6):e66183. 
27. Pholwat S, Liu J, Stroup S, Gratz J, Banu S, Rahman SM, Ferdous SS, Foongladda $\mathrm{S}$, Boonlert D, Ogarkov O, et al. Integrated microfluidic card with TaqMan probes and high-resolution melt analysis to detect tuberculosis drug resistance mutations across 10 genes. MBio. 2015;6(2):e02273.

28. Liu J, Kabir F, Manneh J, Lertsethtakarn P, Begum S, Gratz J, Becker SM, Operario DJ, Taniuchi M, Janaki L, et al. Development and assessment of molecular diagnostic tests for 15 enteropathogens causing childhood diarrhoea: a multicentre study. Lancet Infect Dis. 2014;14(8):716-24.

29. C. Centers for Disease, Prevention. Unexplained Respiratory Disease Outbreak working group activities - worldwide, March 2007-September 2011. MMWR Morb Mortal Wkly Rep. 2012;61(26):480-3.

30. Kodani M, Winchell JM. Engineered combined-positive-control template for real-time reverse transcription-PCR in multiple-pathogen-detection assays. J Clin Microbiol. 2012;50(3):1057-60.

31. Grijalva CG, Nuorti JP, Griffin MR. Antibiotic prescription rates for acute respiratory tract infections in US ambulatory settings. JAMA. 2009;302(7):758-66.

32. Martin-Loeches I, Torres A, Rinaudo M, Terraneo S, de Rosa F, Ramirez P, Diaz E, Fernandez-Barat L, Li Bassi GL, Ferrer M. Resistance patterns and outcomes in intensive care unit (ICU)-acquired pneumonia. Validation of European Centre for Disease Prevention and Control (ECDC) and the Centers for Disease Control and Prevention (CDC) classification of multidrug resistant organisms. J Infect. 2015;70(3):213-22.

33. Dou M, Sanjay ST, Dominguez DC, Liu P, Xu F, Li X. Multiplexed instrumentfree meningitis diagnosis on a polymer/paper hybrid microfluidic biochip. Biosens Bioelectron. 2017;87:865-73.

34. Corless CE, Guiver M, Borrow R, Edwards-Jones V, Fox AJ, Kaczmarski EB. Simultaneous detection of Neisseria meningitidis, Haemophilus influenzae, and Streptococcus pneumoniae in suspected cases of meningitis and septicemia using real-time PCR. J Clin Microbiol. 2001;39(4):1553-8.

35. Cleary TJ, Roudel G, Casillas O, Miller N. Rapid and specific detection of mycobacterium tuberculosis by using the smart cycler instrument and a specific fluorogenic probe. J Clin Microbiol. 2003:41(10):4783-6.

36. Le Monnier A, Abachin E, Beretti JL, Berche P, Kayal S. Diagnosis of listeria monocytogenes meningoencephalitis by real-time PCR for the hly gene. J Clin Microbiol. 2011;49(11):3917-23.

37. Yang W, Cai X, Hao Y, Liu Y, Wang S, Xing R, Gu J, Li C, Yue X, Yuan C, et al. Characterization of Streptococcus suis serotype 2 blood infections using RTqPCR to quantify glutamate dehydrogenase copy numbers. J Microbiol Methods. 2010;83(3):326-9.

38. Vandecasteele SJ, Peetermans WE, Merckx R, Van Eldere J. Quantification of expression of Staphylococcus epidermidis housekeeping genes with Taqman quantitative PCR during in vitro growth and under different conditions. J Bacteriol. 2001;183(24):7094-101.

39. McConnell MJ, Perez-Ordonez A, Perez-Romero P, Valencia R, Lepe JA, Vazquez-Barba I, Pachon J. Quantitative real-time PCR for detection of Acinetobacter baumannii colonization in the hospital environment. J Clin Microbiol. 2012:50(4):1412-4.

40. McCulloch E, Lucas C, Ramage G, Williams C. Improved early diagnosis of Pseudomonas aeruginosa by real-time PCR to prevent chronic colonisation in a paediatric cystic fibrosis population. J Cyst Fibros. 2011;10(1):21-4.

41. Wunder EA Jr, Figueira CP, Santos GR, Lourdault K, Matthias MA, Vinetz JM Ramos E, Haake DA, Picardeau M, Dos Reis MG, et al. Real-time PCR reveals rapid dissemination of Leptospira interrogans after intraperitoneal and conjunctival inoculation of hamsters. Infect Immun. 2016;84(7):2105-15.

42. Brinkman NE, Haugland RA, Wymer LJ, Byappanahalli M, Whitman RL, Vesper SJ. Evaluation of a rapid, quantitative real-time PCR method for enumeration of pathogenic Candida cells in water. Appl Environ Microbiol. 2003;69(3):1775-82.

43. Gago S, Esteban C, Valero C, Zaragoza O, Puig de la Bellacasa J, Buitrago MJ. A multiplex real-time PCR assay for identification of pneumocystis jirovecii, Histoplasma capsulatum, and Cryptococcus neoformans/Cryptococcus gattii in samples from AIDS patients with opportunistic pneumonia. J Clin Microbiol. 2014;52(4):1168-76.

44. Liu J, Gratz J, Maro A, Kumburu H, Kibiki G, Taniuchi M, Howlader AM, Sobuz SU, Haque R, Talukder KA, et al. Simultaneous detection of six diarrheacausing bacterial pathogens with an in-house PCR-luminex assay. J Clin Microbiol. 2012;50(1):98-103.

45. Schabereiter-Gurtner C, Selitsch B, Rotter ML, Hirschl AM, Willinger B. Development of novel real-time PCR assays for detection and differentiation of eleven medically important aspergillus and Candida species in clinical specimens. J Clin Microbiol. 2007;45(3):906-14.

\section{Ready to submit your research? Choose BMC and benefit from:}

- fast, convenient online submission

- thorough peer review by experienced researchers in your field

- rapid publication on acceptance

- support for research data, including large and complex data types

- gold Open Access which fosters wider collaboration and increased citations

- maximum visibility for your research: over $100 \mathrm{M}$ website views per year

At BMC, research is always in progress.

Learn more biomedcentral.com/submissions 